\title{
Women Participation in Indian Banking Sector: Issues and Challenges
}

\author{
Ramya K. R. ${ }^{1}$, Dr. A. Raghurama ${ }^{2}$ \\ ${ }^{1}$ Research Scholar, Department of Studies and Research in Commerce, Mangalore University, Mangalagangotri-574199, Karnataka, India \\ ${ }^{2}$ Professor, Department of Studies and Research in Commerce, Mangalore University, Mangalagangotri-574199, Karnataka, India
}

\begin{abstract}
Nationalization of the Indian Banking Sector in 1969 served as the first major step to reduce gender discrimination against women in banking and insurance sectors and has provided opportunity for women empowerment. The pattern of Indian women's employment has changed markedly since the 1970s. Technology has indeed played a significant role in this change. Increasing women literacy, growing economic pressure, and desire to gain economic and social independence are pushing womenfolk to take up gainful career in banks. The phenomenal growth of banks has created massive employment opportunities for the educated women of our nation. The women job-seekers find jobs in banks more attractive and more suitable to their nature. In this paper an attempt has been made to identify the general sentiments, challenges and opportunities of women employees in the Indian Banking Industry, which is the life blood of the Indian economy.
\end{abstract}

Keywords: Women, banking sector, empowerment, Opportunities

\section{Introduction}

In Vedic times women occupied the highest place in society. They were given all opportunities to develop themselves, socially, intellectually and morally. They were given thorough education. Similarly there is a positive change in the present society, which is focusing on women empowerment. The progress of any country is intimately linked to its ability to develop and use its human resource effectively. This is particularly true in a developing country like India. Women, as a significant part of this human resource pool, play a vital role in the economic, social and political development of India. Nationalization of the Indian Banking Sector in 1969 served as the first major step to reduce gender discrimination against women in banking sector and that provided opportunity for women empowerment. The pattern of Indian women's employment has changed significantly since the 1970's. Many major Indian banks are hiring highly qualified young Indian women to their administrative levels and they are showing remarkable growth over the years.

\section{Objectives of the study}

1) To identify the problems of women in the Indian banking sector.

2) To suggest the measures to overcome the problems.

\section{Methodology}

The present study is based on secondary data and the data were collected from journals, books, news papers, RBI annual reports and other websites.

\section{Spotlight on Women in Indian Banks}

The number of talented women with a finance background joining into the banking sector is increasing every year. Women constitute a little over $11 \%$ of the workforce in the banking industry (Khandelwal, 1988).The Indian government appointed a committee in the year 2009, to look at human resource issues of public sector banks under the chairmanship of former Chairman and Managing Director of Bank of Baroda and Anil Khandelwal. The Khandelwal Committee made some far-reaching recommendations, some of which were accepted by banks and the government. According to the committee's report published in 2010, at that time women accounted for only 17 per cent of employees in state-run banks, of which only 2.7 per cent of women were in executive positions.

"Women started joining banks only in the late 70 s and mostly at clerical levels. With career progression reaching an apex, the industry is likely to have more women at the top in the years to come. And when they do come, they are not just considered women, but as leaders and role models," says Subhalakshmi Panse, chairperson-cum-managing director (CMD) of Allahabad Bank, who took over the reins in 2012. Not only in the higher levels that we can see had the involvement of women but also in the clerical levels also women are more attracted. Secured family life, attractive salary, favourable working conditions and the stability in work are some of the reasons that make this sector more preferable to women.

According to a study by Standard Chartered Bank about women on corporate boards in India, the financial sector performs best in terms of gender diversity, nine of the eleven banks listed on BSE-100 have a woman on their board and two of these banks have a female CEO. In fact, through the recent recession, Reserve Bank of India had two women deputy governors on board, Usha Thorat and Shyamala Gopinath.

According to the 2013 Catalyst Census: Fortune 500 Women Executive Officers and Top Earners, women represented 17.6 percent of executives and 17.9 percent of the board of directors in the finance and insurance sector. In 2012, women represented 23.1 percent of all senior officers in 


\section{International Journal of Science and Research (IJSR) \\ ISSN (Online): 2319-7064}

Index Copernicus Value (2013): 6.14 | Impact Factor (2014): 5.611

Financial Post 500 companies, and in 201311.4 percent of chief financial Officers of Fortune 500.

The banking Sector in India which was male dominated till 1980's, in last three decades the gender equality became fairly poised. Women executives like Chanda Kochhar (CEO, ICICI Bank), and Naina Lal Kidwai (CEO,HSBC), Arundathi Bhattacharya,(CMD SBI), Shikha Sharma(CEO and MD, Axis Bank), Usha Ananthasubramanian (CEO, MD Punjab National Bank), are contributing a lot to the bank's growth. The below table presents the class-wise distribution of all scheduled commercial banks employees and women representation in it. From the below table we can observe that the number of female employees in the banking sector is increasing year after year.

Table 1: Group-Wise Distribution of Employees Of All Scheduled Commercial Banks According To Category Since March 2005-2014

\begin{tabular}{|c|c|c|c|c|c|c|c|c|}
\hline \multirow{2}{*}{ Year } & \multicolumn{4}{|c|}{ TOTAL EMPLOYEES } & \multicolumn{4}{c|}{ OF WHICH : FEMALES } \\
\cline { 2 - 9 } & Officers & Clerks & Subordinates & Total & Officers & Clerks & Subordinates & Total \\
\hline 2014 & $6,40,869$ & $4,31,842$ & $1,81,244$ & $12,53,955$ & $1,29,345$ & $1,25,795$ & 22,652 & $2,77,792$ \\
\hline 2013 & $5,51,712$ & $4,84,975$ & $1,84,044$ & $12,20,731$ & 95,507 & $1,15,233$ & 22,436 & $2,33,176$ \\
\hline 2012 & $5,02,938$ & $4,81,421$ & $1,90,790$ & $11,75,149$ & 84,375 & 107,826 & 23,113 & 215,314 \\
\hline 2011 & $4,70,144$ & $4,02,521$ & $1,78,220$ & $10,50,885$ & 67,958 & 100,999 & 17,827 & 186,784 \\
\hline 2010 & $4,01,060$ & $3,49,360$ & $1,75,608$ & $9,26,028$ & 50,507 & 86,351 & 16,525 & $1,53,383$ \\
\hline 2009 & $3,51,841$ & $3,42,930$ & $1,74,641$ & $8,69,412$ & 41,538 & 79,174 & 17,382 & 138,094 \\
\hline 2008 & $3,34,884$ & $3,33,414$ & $1,70,471$ & $8,38,769$ & 36,091 & 72,102 & 15,208 & $1,23,401$ \\
\hline 2007 & $3,47,662$ & $3,66,700$ & $1,85,045$ & $8,99,407$ & 34,441 & 81,031 & 17,252 & $1,32,724$ \\
\hline 2006 & 330,093 & $3,84,821$ & $1,85,210$ & $9,00,124$ & 30,566 & 84,843 & 17,339 & $1,32,78$ \\
\hline 2005 & 313,863 & 396,812 & 189,758 & 900,433 & 27,282 & 86,094 & 17,113 & 130,489 \\
\hline
\end{tabular}

The above table depicts the distribution of employees of all scheduled commercial banks in India since 2005-2014, it is clear from the table that every year the number of women entering into the banking sector has been increasing significantly, that is from $1,30,489$ in 2005 , to $2,77,792$ in the year 2014, out of which 1,29, 345 are in the officers position. That means 1,47,303 and optimal women entered into the banking sector, within a period of 9 years. The increasing number of women employees in Indian banking sector shows that the gender discrimination in the workplace is being reduced since past few decades.

\section{Problems of Women Employees in Indian Banking Sector}

The banking and insurance sectors today offer more prospects for jobs for women - both qualitatively and quantitatively. However there are some common problems faced by women managers, officers and clerical groups in banking and insurance sector, in the course of their careers. These include the burden of the dual role, sexual harassment in the workplace, the refusal of men to accept women as colleagues or seniors, and the lack of solidarity among women. A lot of women play both primary breadwinner and primary care taker role which create a tension most men do not experience when juggling work and personal responsibilities.

According to a study by Kamala Srinivasan (1991) 50 per cent of women complained that extra work is always shunted to women. They also complained about sexual harassment from colleagues, managers, or customers. Women also felt dissatisfied that they were not sent out for training. Some obstacles arise from women's specific difficulties in demanding promotion - because promotions are linked with transfers; or they have difficulties in working late; or because women shy away from responsibility, having a low opinion of their own abilities and a negative attitude to accepting recognition (Mankidy, 1986). Some women employees feel that these constraints are intensified by being forced to adopt the behaviour of the 'successful manager or officer' which has been established by men. They argue that women could find their own strategies which would achieve the same result (Mankidy, 1988). Women frequently suffer subtle forms of discrimination that tend to get worse as they progress up the career ladder. Their lack of visibility is a disadvantage that manifests itself when job assignments and selections for training programs are made and they tend to be excluded (Goverman, 1992). Indian women managers' expresse interest to be included in informal networks on the job (Bhatnagar, 1988)

The biggest challenge lies in changing the stereotypes, assumptions and biases about what is required for leadership and success that permeate the culture of financial institutions. The senior management of financial firms have always been almost exclusively men and they remain the strongly dominant group. This means that what is in fact a gender-based bias may be perceived by most senior managers to be no more than commonsense meritocracy. These assumptions relate to both day-to-day working practices and also the qualities required for leadership.

Certain behaviors are perceived differently when exhibited by men and women. For example, an assertive man might be perceived as being a strong leader whereas a similarly assertive woman might be perceived to be "strident" or "bossy" (adjectives rarely applied to men). And as pointed out earlier, the character traits traditionally associated with leadership in financial firms have been typically masculine.

The discrimination experienced by women working in banks is mainly in terms of the lack of infrastructural facilities, the transfer policy, and assumptions that women would not be interested in training or in promotions. 


\section{International Journal of Science and Research (IJSR) \\ ISSN (Online): 2319-7064}

Index Copernicus Value (2013): 6.14 | Impact Factor (2014): 5.611

\section{Strategies to Overcome from the Problems}

The first step in addressing the unconscious biases and assumptions is to get people recognize and understand these in their own thoughts and behaviour. Management may require some training to help them do this. Some firms are taking measures to improve awareness of gender issues, using workshops and reverse mentoring,

The second, and perhaps the most important step in eliminating biases is ensuring that these assumptions about what it takes to be an effective leader do not influence hiring decisions, promotions, the allocation of career opportunities and performance evaluations. To bring this about, senior management should change their recruitment and promotion criteria and set targets for attracting and developing a diverse set of leaders.

Employers who want to help women advance to the top must do more to make allowances for life outside of work. They must make sure that even ambitious and talented employees do not feel that they will have to work hours incompatible with a family life. Women in banking who require flexible working conditions need to feel emotionally empowered to take full advantage of them.

The Women's Wing of the AICOBOO has been taking up these issues systematically. One outcome of their work has been the charter of demands they submitted to their union confederation. These included:

6.1 Infrastructural facilities such as creches and day care centres.

6.2 Provision of hostels for working women, accommodation for divorced, separated and widowed women with children.

6.3 Special leave with a lien on service, for up to say five years, to meet certain contingencies specific to women, extending this facility to men also whenever required.

6.4 Provision for a woman with a child less than three years old to work for fewer hours and receive proportionate pay.

6.5 Family pension and voluntary retirement for men and women after twenty years of service.

6.6 Provision for flexi-hours and part-time employment in suitable cases.

6.7 Although maternity leave ( 12 weeks in all) is regarded as fairly satisfactory, additional provisions required are medical benefits, hospitalization, leave for the purpose of child care, paternity leave for at least ten days, and further leave for those who have to look after an infant in special circumstances. The Ministry of Labour is expected to amend the Maternity Benefit Act, 1961, which presently entitles women to 12 weeks of maternity benefit whereby employers are liable to pay full wages for the period of leave.

6.8 The specific demands put forward by the Women's Wing include a uniform transfer policy in all banks for women officers, and a cell to deal with women's issues in every bank's personnel department. They are currently trying to formulate demands relating to training programmes and time off for women to do union work.

Similarly the All India Bank Employees Association (AIBEA) initiated a women's wing of the union to take up issues specially affecting women. The Reserve Bank of India has a Women's Forum for the same purpose. The unions in the LIC have begun to organize women-only meetings and workshops. The Insurance Employees Association decided in 1991 to organize women employees more effectively, as the number of women employees was increasing day by day, with over 75 per cent of the new recruits being women. The association has demanded crèches facilities, special leave and better working conditions for women, and the removal of hidden discrimination.

Each PSB has to come out with a HRD plans for development of women and SC / ST employees. A special HRD effort has to be put in place for developing these groups in key skills of banking. Training strategy to focus on staff working in rural areas and women employees and priority to be accorded for regular in-house training to rural staff. Many of the Banks do not have transfer policy which gives consideration to the special problems which female officers/employees face vis-a-vis their male counterparts. Government of India, Ministry of Finance and Department of Financial Services has issued guidelines to all Public Sector Banks including IDBI \& SBI Associates, so that transfers of female officers and employees can be considered with compassion and their hardship can be mitigated to the extent possible. National Institute of Bank management (NIBM) is also organising workshops for female clerical staff, officers and managers.

One way of improving prospects for women could be to restructure the work, for example with flexible working hours, part time job assignments, split location positions performed partly at home and job and job sharing (Mankidey 1988). Banks should be encouraged to have a formal mentorship program in which new employees are assigned mentors who are responsible for helping the new recruit to fit into the central core of the organization.

Finally, if financial firms are to make progress on increasing diversity, they cannot treat it as a side-line activity. Increasing diversity must be a priority for the most senior management in the firm and not merely for HR.

\section{Conclusion}

Increasing women literacy, growing economic pressure, and the burning desire to gain economic and social independence are pushing womenfolk to take up gainful career. The phenomenal growth of banks has created massive employment opportunities for the educated women of our nation. Feminine traits no doubt help them perform better than male colleagues in certain aspect of delivery of banking service Researches have shown that having women on boards provides genuine value addition to decision-making. We have a distance to go, especially in the larger society, 
whose attitudes determine how women are viewed and valued, including in corporate life.

\section{References}

[1] Bhatnagar, D. (1988). "HRD for women employees in banks". In A. K. Khandelwal, (ed.) Human Resources Development in Banks. Oxford and IBH Publishing Company, New Delhi.

[2] Goverman, J. (1992). "Women in science should look within". Los Angeles Times, November 11

[3] http://shodhganga.inflibnet.ac.in:8080/jspui/bitstream/10 603/25502/7/07_chapter\%201.pdf

[4] http://timesofindia.indiatimes.com/business/india/whatmakes-women-successful-in-Indisn-Bankingindustry/articleshow/6584040.cms

[5] http://www.empowerwomen.org/en/circles/makefinancial-markets-work-for women/women-employment-in-the-financesector\#sthash.vAlTyLXd.dpuf

[6] http://indianexpress.com/article/india/india-newsindia/govt-to-increase-maternity-leave-in-pvt-sectorfrom-12-to-26-weeks/\#sthash.TjLMpt2L.dpuf.

[7] http://www.newindianexpress.com/business/Financial sector-bankingon women2013/08/11/article1728257.ece

[8] https://www.rbi.org.in/scripts/AnnualPublications.asx?h ead $=$ Basic + Statistical + Return

[9] http://news.efinancialcareers.com/uk- en/184267/lifeisnt-geting-easier-women-banking.

[10] Kamala Srinivasan (1991), "Women in Banking and Professional Struggles - Women and Development", Discovery, Vol. 1, New Delhi.rce

[11] Khandelwal and Anil.K (1998), “ Human ResourceDevelopment in Banks''Oxford and IBH Publishing company, New Delhi.

[12] Mankidy, A. (1986), "Women Employees: A New Dimension to Human Resource Management in Banks", Indian Banks' Association, Special issue

[13] Mankidy, A. (1988), "Towards Better Functioning of Women Managers in Banks", National Institute of Bank Management, Pune.

[14] Mankidy, A. (1991), "Making space for women managers". Economic Times, $13^{\text {th }}$ June

[15] Parvathy. V.K.(2013), "Role of Indian women in banking sector", March 4, the Indian/role-of-women-inthe-bankingindustry/fusion.http;//Indianfusion.aglasem.com/42173

[16] Srinivas, M. N. (1978). "The Changing Position of Indian Women”. Oxford University Press Bombay.

\section{Author Profile}

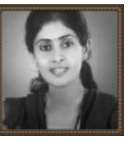

Ramya.K.R received the M.H.R.D and M.COM. Degrees from Mangalore University Mangalagangothri, in the year 2009 and 2013 respectively, at present Perusing Ph.D in the department commerce at Mangalore University.

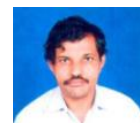

Dr. A. Raghurama received the M.COM degree and $\mathrm{Ph} . \mathrm{D}$ from Mangalore University and working as Professor in Dept. of Commerce at Mangalore University, His Specialization areas are Advanced Banking \& International Finance, Micro, Small and Medium Enterprises Management \& Rural Development. 